\title{
PERBEDAAN PERILAKU LEKAT BAYI \\ PADA ORANGTUA ANTARA YANG DIBERI ASI EKSKLUSIF DENGAN YANG TIDAK DIBERI ASI EKSKLUSIF \\ (Studi pada Bayi Umur 6 Bulan - 3 Tahun di Kecamatan Candi \\ Kabupaten Sidoarjo)
}

\author{
Qurrotul A'yun, M.Psi, Psi \\ (Dosen Fakultas Psikologi Umsida) \\ Inayah
}

\section{Abstrak}

Air Susu Ibu (ASI) merupakan makanan yang paling sempurna bagi bayi. Memberikan ASI berarti memberikan zat-zat gizi yang bernilai gizi tinggi yang dibutuhkan untuk pertumbuhan dan perkembangan saraf dan otak, serta mewujudkan ikatan emosional antara ibu dan bayinya.

Teori belajar mengatakan bahwa kelekatan antara ibu dan anak dimulai saat ibu menyusui bayi sebagai proses pengurangan rasa lapar yang menjadi dorongan dasar. Susu yang diberikan ibu menjadi primary reinforcer dan ibu menjadi secondary reinforcer. (Gewirtz dalam Hetherington dan Parke, 1999 dalam Ervika 2000, http//Library usu.co.id).

Tujuan dari penelitian ini adalah untuk mengetahui perbedaan perilaku lekat bayi pada orang tua antara yang diberi ASI Eksklusif dengan yang tidak diberi ASI Eksklusif.

Dari hasil Uji t probabilitasnya adalah $<0,05$ yaitu 0,000 berarti hipotesis diterima. Berdasarkan tabel $t$-test, $t_{\text {tabel }}$ pada taraf kepercayaan $95 \%$ maka didapatkan nilai $t_{\text {tabel }}$ sebesar 1,645. Oleh karena $t_{\text {hitung }}>t_{\text {tabel }}$ yaitu sebesar 13,832 maka hipotesis diterima. Dengan demikian berdasarkan uji tersebut di atas terdapat perbedaan Perilaku lekat bayi pada orang tua antara yang diberi ASI eksklusif dengan yang tidak diberi ASI eksklusif.

\section{Latar Belakang}

Pemberian Air Susu Ibu (ASI) pada bayi merupakan cara terbaik bagi peningkatan kualitas sumber daya manusia sejak dini yang akan menjadi penerus bangsa. ASI merupakan makanan yang paling sempurna bagi bayi. Pemberian ASI berarti memberikan zat-zat gizi yang bernilai gizi tinggi yang dibutuhkan untuk pertumbuhan dan perkembangan saraf dan otak, serta mewujudkan ikatan emosional antara ibu dan bayinya.

Beberapa faktor keberhasilan dalam menyusui yaitu dengan menyusui secara dini dengan posisi yang benar, teratur, dan eksklusif. Serta yang perlu mendapat perhatian adalah bagaimana ibu tetap memberikan ASI kepada bayinya secara eksklusif sampai 6 (enam) bulan dan dapat dilanjutkan sampai anak berumur 2 (dua) tahun.

Organisasi Kesehatan Dunia (WHO) merekomendasikan agar bayi baru lahir mendapat ASI eksklusif (tanpa tambahan apa-apa) selama enam bulan. Prof. Rulina Suradi, Spa (K) juga mengatakan bahwa pemberian ASI lebih aman bila dihentikan saat anak umur 2 tahun. (http://www.sonnenvogel.com)

Dalam Alquran disebutkan: "Para ibu hendaklah menyusukan anak-anaknya selama dua tahun penuh, yaitu bagi yang ingin menyempurnakan penyusuan. Dan kewajiban ayah memberi makan dan pakaian kepada para ibu dengan cara ma'ruf. Seseorang tidak dibebani melainkan menurut kadar kesanggupannya. Janganlah seorang 
ibu menderita kesengsaraan karena anaknya dan seorang ayah karena anaknya, dan warispun berkewajiban demikian. Apabila keduanya ingin menyapih (sebelum dua tahun) dengan kerelaan keduanya dan permusyawaratan, maka tidak ada dosa atas keduanya. Dan jika kamu ingin anakmu disusukan oleh orang lain, maka tidak ada dosa bagimu apabila kamu memberikan pembayaran menurut yang patut. Bertakwalah kamu kepada Allah dan ketahuilah bahwa Allah Maha Melihat apa yang kamu kerjakan" (AlBaqarah 2: 233). Hikmah ayat yang terkandung dalam kitab Suci Alqur'an tersebut, setidaknya menekankan bahwa ASI sangat penting. Demikian juga seorang ibu wajib memberikan ASI sampai anaknya genap usia 2 tahun.

ASI mempunyai keunggulan dan bermanfaat bagi ibu yang menyusuinya, sedangkan keunggulan dan manfaat menyusui dapat dilihat dari beberapa aspek yaitu: aspek gizi, aspek imonologi, aspek psikologi, aspek kecerdasan, neorologis, emonomis dan aspek penundaan kehamilan. Pada aspek psikologi pemberian ASI diusia bayi berperan besar dalam membentuk kelekatan bayi dan ibunya.

Teori belajar mengatakan bahwa kelekatan antara ibu dan anak dimulai saat ibu menyusui bayi sebagai proses pengurangan rasa lapar yang menjadi dorongan dasar. Susu yang diberikan ibu menjadi primary reinforcer dan ibu menjadi secondary reinforcer. Kemampuan ibu untuk memenuhi kebutuhan dasar bayi menjadi dasar terbentuknya kelekatan. Teori ini juga beranggapan bahwa stimulasi yang diberikan ibu pada ayi, baik itu visual, auditori dan taktil dapat menjadi sumber pembentukan kelekatan (http://library.usu.ac.id)

Melihat latar belakang diatas dan pentingnya ASI Eksklusif bisa menumbuhkan perilaku Lekat bagi bayi terhadap orang tua maka peneliti termotivasi untuk membuat penelitian tersebut, harapannya para ibu dapat memberikan ASI secara Eksklusif sehingga kelak dapat terpenuhi pertumbuhan fisik, intelektual dan kognitif serta perkembangan psikologi anak secara optimal.

\section{Kajian Teori}

Pengertian Kelekatan

Menurut Mc Cartney dan Dearing (2002), Kelekatan merupakan suatu ikatan emosional yang kuat yang dikembangkan anak melalui interaksinya dengan orang yang mempunyai arti khusus dalam kehidupannya, biasanya orang tua. (http://library.usu.ac.id)

Bowlby (dalam Monk dkk, 2006: 70) menyatakan bahwa hubungan ini akan bertahan cukup lama dalam rentang kehidupan manusia yang diawali dengan kelekatan anak pada ibu atau figur lain pengganti ibu. Pengertian ini sejalan dengan apa yang dikemukakan Ainsworth mengenai kelekatan.

Ainsworth mengatakan bahwa kelekatan adalah ikatan emosional yang dibentuk seorang individu dengan orang lain yang bersifat spesifik, mengikat mereka dalam suatu kedekatan yang bersifat kekal sepanjang waktu.

Kelekatan adalah sebuah proses berkembangnya ikatan emosional secara timbal balik antara bayi/anak dengan pengasuh (orang tua).

\section{Teori-teori Kelekatan}


Ada beberapa tgeori yang mencoba menjelaskan kelekatan, antara lain:
a. Teori psikoanalisa
b. Teori Belajar
c. Teori Perkembangan Kognitif
d. Teori Etologi

\section{Pengertian Perilaku Lekat}

Dalam teori kepribadian Thomae yang telah dikemukakan dalam tahun 1944 dalam "Das Wesen der menschlicein Antriebsstruktur" dikemukakan bahwa perilaku lekat (attachment behavior) manusia merupakan hal yang sentral. Ia berpendapat bahwa hal yang penting dalam perkembangan yang sehat adalah kemampuan anak untuk dapat mengembangkan perilaku lekat tadi. (Monk dkk, 2006:68).

Menurut Ainsworth (1973) bahwa perilaku lekat adalah berbagai macam perilaku yang dilakukan anak untuk mencari, menambah dan mempertahankan kedekatan serta melakukan komunikasi dengan figur lekatnya. (dalam Ervika 2000, http://library usu.ac.id)

Perilaku lekat pada anak kecil dapat dilihat sebagai berikut:

a. Menangis bila obyek lekatnya pergi.

b. Senang dan ketawa lagi bila obyek lekatnya kembali

c. Mengikuti dengan mata arah menghilangnya obyek lekat.

\section{Bentuk-bentuk Perilaku Lekat}

Perilaku lekat pada manusia sangat bervariasi dan dapat tampak pada semua anak. Perilaku ini dipergunakan untuk mencari dan mempertahankan kedekatan serta bertujuan (goal corrected) hasil yang diharapkan dari perilaku ini adalah kedekatan dengan ibu.
Menurut Bowlby dan Ainsworth (dalam Ervika 2000, http://library usu.ac.id) secara umum pengelompokan perilaku lekat sebagai berikut:

\section{Signaling Behavior}

Efek dari perilaku ini adalah mendekatnya ibu pada anak. Perilaku ini sebetulnya bagi anak diharapkan untuk mendapatkan dan meningkatkan kedekatan dengan ibu. Kondisi anak dan pengaruhnya terhadap perilaku ibu (maternal behavior) berbeda-beda, misalnya, anak menangis (signaling behavior) maka ibu akan datang dan menggendong (maternal behavior). Tetapi jika anak "meraban" maka ibu akan tersenyum. Ada beberapa bentuk perilaku yang termasuk signaling behavior, antara lain:
a. Menangis
b. Tesenyum dan Meraban
c. Tanda Acungan Tangan (gesture raised arms)
d. Mencoba menarik perhatian

\section{Fase-fase dalam perilaku Lekat}

Menurut Bowlby (dalam Crain, 2007:67-73) terdapat beberapa fase dalam perilaku lekat:

Fase 1 (lahir sampai 3 bulan)

Fase 2 (3 sampai 6 bulan)

Fase 3 ( 6 bulan sampai 3 tahun)

Fase 4 (3 tahun sampai akhir masa kanak-kanak)

\section{Perkembangan Kepribadian dan Perkembangan Sosial}

Menurut Bowlby (dalam Monk, dkk, 2006, hal 109-112) terdapat dua teori tentang perkembangan kepribadian dan sosial:

Teori Diferensia

Teori Paralel

Faktor-faktor Penyebab Timbulnya Kelekatan 
Beberapa pendapat tentang timbulnya perilaku lekat, yaitu:

\section{Hipotesis nafsu sekunder}

Pendapat ini mengatakan bahwa ketergantungan sosial terjadi karena ketergantungan fisik melalui proses belajar, misalnya bila nafsu primer anak selalu terpenuhi oleh orang tertentu atau bila dekat dengan orang tersebut maka orang tertentu itu akan memperoleh nilai positif bagi anak dan terjadilah pada anak nafsu sekunder terhadap orang tertentu itu, yaitu orang yang mengasuhnya. Anak kemudian akan melekatkan dirinya pada orang yang mengasuhnya itu.

\section{Sifat kognitif persepsual}

Anak merasa tertarik pada seseorang karena sifat-sifat persepsualnya atau sifat-sifat yang dapat dilihat oleh anak. Pada mulanya roman muka manusia mempunyai daya tarik yang alami bagi anak. Bila anak seringkali melihat orang tertentu maka ia akan mengenal sifat-sifat khusus orang tertentu itu. Bila orang tersebut ada didekat anak maka anak akan merasa aman. Bila ada orang asing datang, anak akan bersikap negatif terhadap orang yang asing tersebut. Disini timbulnya kelekatan diterangkan oleh proses belajar pengamatan, pengamatan berulangulang terhadap orang-orang tertentu menimbulkan kelekatan.

\section{Control theory of attachment behavior}

Bowlby (1972) berpendapat bahwa timbulnya kelekatan anak terhadap figure lekat (biasanya ibu) adalah suatu akibat menjadikannya aktif suatu sistem perilaku (behabioral system) yang membutuhkan kedekatan dengan ibu. (Monk, dkk, 2006: 70).

Ada dua macam perilaku yang menyebabkan seseorang dipilih sebagai obyek kelekatan, yaitu:
a. Sering mengadakan reaksi terhadap perilaku anak yang

dimaksudkan untuk menarik perhatian.

b. Sering membuat interaksi secara spontan dengan anak.

\section{Faktor-faktor yang mempengaruhi kelekatan}

$$
\text { Bowlby (dalam Gunarsa, }
$$
1997:180) mengatakan bahwa perpisahan yang terjadi pada anak yang berada pada usia antara enam bulan sampai satu tahun ketika anak baru membentuk kelekatan dengan tokoh tertentu, akan menimbulkan banyak persoalan, kesulitan dan banyak membutuhkan banyak waktu untuk memulihkan ke keadaan semula.

Perpisahan yang lama tanpa ada tokoh pengganti akan menimbulkan akibat yang menyulitkan diri anak maupun orang lain. Secara khusus terlihat pada kehidupan dan perwujudan emosinya. Kejengkelan yang dialami karena harus terpisah dari tokoh atau ibunya mempengaruhi reaksi-reaksi emosi terhadap lingkungan yang sebaliknya akan memberikan pula jawaban terhadap anak. Demikian pula bilamana sering terjadi perpisahan tanpa ada tokoh pengganti yang benarbenar bisa memenuhi semua kebutuhan anak sesuai kebutuhankebutuhan yang sedang dialami pada tahapan perkembangannya.

Kuat lemahnya keterikatan antara anak terhadap ibu atau tokoh pengganti mempengaruhi reaksi-reaksi yang akan diperlihatkan anak, kalau terjadi perpisahan. Keterikatan yang longgar menyebabkan anak tidak terlalu merasa kehilangan bahkan mudah untuk mencari atau memeroleh pengganti dengan siapa anak merasa lebih terikat.

Pola-pola Perilaku Lekat 
Menurut Mary Ainsworth (dalam Crain, 2007:73) terdapat tiga macam pola kelekatan, yaitu:

1. Bayi-bayi yang merasa tetap aman (Scurily attached infants).

2. Bayi-bayi merasa tidak aman dan ingin menghindar (Insecureavoident infants).

3. Bayi-bayi yang merasa tidak aman namun bersikap ambivalen (Insecure ambivalent infants).

\section{Dampak Problem Kelekatan}

Anak-anak yang kebutuhan emosionalnya tidak terpenuhi akibat problem kelekatan yang dialami, berpotensi mengalami masalah intelektual, emosional, moral dan sosial dikemudian hari. (dalam Jacinta FR, 2002, e. psikologi.com).

1. Masalah Intelektual
a. Kemampuan berfikir
b. Kesulitan belajar
c. Sulit mengendalikan dorongan

2. Masalah Emosional
a. Gangguan bicara
b. Gangguan pola makan
c. Perkembangan konsep diri yang negatif

3. Masalah moral dan sosial

\section{Cara membangun Kelekatan yang baik dengan Anak}

Menurut Jacinta (dalam

e.psikologi.com) terdapat beberapa cara untuk membangun kelekatan yang baik dengan anak:

1. Siapkan mental untuk menjadi orang tua

2. Ciptakan komunikasi yang hangat sejak dini

3. Tanggapilah tangisan bayi atau anak secara positif

4. Upayakan kebersamaan dalam keluarga inti

\section{ASI Eksklusif}

ASI Eksklusif adalah ASI yang diberikan pada bayi umur 0-6 bulan tanpa tambahan cairan lainnya seperti susu formula, madu, air teh, air putih dan tanpa bahan makanan padat lain seperti pisang, pepaya, bubur susu, biscuit, bubur nasi dan tim (Utami R, 2000:7).

Menurut Arifin (dalam www.Digitized by USU.co.id) mengatakan bahwa ASI merupakan makanan alamiah yang pertama dan utama bagi bayi baru lahir. ASI dalam jumlah cukup merupakan makanan terbaik untuk bayi dan dapat memenuhi kebutuhan gizi bayi selama empat bahkan enam bulan pertama.

\section{Keunggulan dan Manfaat ASI}

Keunggulan dan manfaat menyusui dapat dilihat dari beberapa aspek yaitu:

\section{Aspek Gizi}

- Manfaat kolostrum

- Komposisi ASI

- Komposisi Taurin, DHA dan AA pada ASI.

\section{Aspek Imunologik}

ASI mengandung zat anti infeksi, bersih dan bebas kontaminasi. Immonoglobulin $A$ (Ig A) dalam kolostrum atau ASI kadarnya cukup tinggi. Sekretari Ig A tidak diserap tetapi dapat melumpuhkan bakteri patogen E. coli dan berbagai virus pada saluran pencernaan. Laktoveri yaitu sejenis protein yang merupakan komponen zat kekebalan yang mengikat zat besi disaluran pencernaan. Lysosim, enzym yang melindungi bayi terhadap bakteri (E. coli dan salmonella) dan virus jumlah lysosim dalam ASI 300 kali lebih banyak dari pada susu sapi.

\section{Aspek Psikologi}

Menyusui dipengaruhi oleh emosi ibu dan kasih sayang terhadap bayi akan meningkatkan produksi 
hormon terutama oxitosin yang pada akhirnya akan meningkatkan produksi ASI. Ikatan kasih sayang ibu-bayi terjadi karena berbagai rangsangan seperti sentuhan kulit (Skin to skin contact). Bayi akan merasa aman dan puas karena bayi merasakan kehangatan tubuh ibu dan mendengar denyut jantung ibu yang sudah dikenal sejak bayi masih didalam rahim.

Dr. Ariani (dalam http://parentingislami.wordpress.com) mengatakan bahwa proses menyusui akan memperkuat ikatan batin antara ibu dan anak. Ikatan batin yang erat, mesra dan selaras yang diciptakan oleh awal dan lebih permanen sangat penting.

\section{Aspek Kecerdasan}

Interaksi ibu-ibu dan kandungan nilai gizi ASI sangat dibutuhkan untuk perkembangan sistem syaraf otak yang dapat meningkatkan kecerdasan bayi. Penelitian menunjukkan bahwa IQ pada bayi yang diberi ASI memiliki IQ poin 4.3 point lebih tinggi pada usia 18 bulan, 4-6 point lebih tinggi pada usia 3 tahun dan 8.3 point lebih tinggi pada usia 8.5 tahun, dibandingkan pada bayi yang tidak diberi ASI.

\section{Aspek Neorologis}

Dengan menghisap payudara, koordinasi syaraf menelan, menghisap dan bernafas yang terjadi pada bayi baru lahir dapat lebih sempurna.

\section{Aspek Ekonomis}

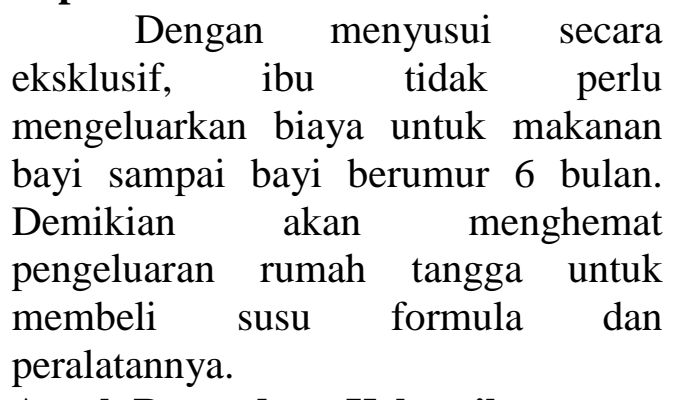

\section{Aspek Penundaan Kehamilan}

Dengan menyusui secara eksklusif dapat menunda haid dan kehamilan, sehingga dapat digunakan sebagai alat kontrasepsi alamiah yang secara umum dikenal sebagai Metode Amenorea laktasi (MAL).

\section{Keuntungan ASI}

Menurut Utami R, (2001:7-10) terdapat beberapa keuntungan dalam pemberian ASI yaitu:
a. ASI sebagai nutrisi.
b. ASI meningkatkan daya tahan tubuh.
c. ASI meningkatkan jalinan kasih sayang.

\section{Kerugian Pemberian Susu Formula}

Menurut Utami R (dalam www.kompas.co.id) pemberian air susu buatan mempunyai banyak kerugian antara lain:
1. Pengenceran yang salah
2. Kontaminasi mikroorganisme
3. Dapat menyebabkan alergi
4. Susu sapi menyebabkan diare kronis

\section{Metode Penelitian}

Pendekatan penelitian yang digunakan dalam penelitian ini adalah pendekatan kuantitatif, yaitu dengan menggunakan angka-angka, adapun rancangan penelitian yang digunakan dalam penelitian ini merupakan jenis rancangan non eksperimental.

Pada penelitian ini mengambil lokasi di Kecamatan Candi Kabupaten Sidoarjo dengan alasan sebagai berikut:

1. Hasil laporan bulanan setiap desa di Puskesmas Candi, bayi yang diberi ASI Eksklusif sedikit sekali, yaitu 24,4\%.

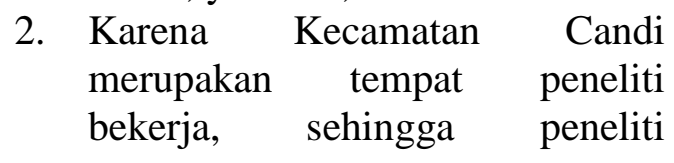


mengetahui permasalahan yang ada di wilayah tersebut.

Dalam penelitian ini populasi yang digunakan adalah semua ibu yang mempunyai anak umur 6 bulan 3 tahun baik yang diberi ASI Eksklusif yang tesebar di delapan desa, Kecamatan Candi, yang keseluruhan populasi berjumlah 1.598 bayi. Dari jumlah populasi tersebut peneliti mengambil $10 \%$ dengan rincian 1.598 x 10/100 sama dengan 139 dibulatkan menjadi 160 responden. Jadi 80 bayi yang diberi ASI Eksklusif dan 80 bayi yang tidak diberi ASI Eksklusif.

Teknik yang digunakan dalam penelitian ini adalah teknik Purpossive Sampling, yaitu pemilihan sampel berdasarkan atas ciri-ciri atau karakteristik yang telah ditentukan sebelumnya (Arikunto, 1993:128). Adapun sampel yang dipilih memiliki karakteristik sebagai berikut:

1. Ibu yang mempunyai anak umur 6 bulan sampai 3 tahun.

2. Ibu yang memberi ASI Eksklusif maupun yang tidak memberi ASI Eksklusif.

3. Pengasuhan di rumah tidak oleh baby sitter / keluarga yang lain.

Teknik pengumpulan data yang digunakan dalam penelitian ini adalah sebagai berikut:

1. Dokumentasi

Dokumentasi adalah ditujukan untuk memperoleh data langsung dari tempat penelitian. Dokumentasi dalam penelitian ini didapatkan dari hasil laporan kegiatan delapan desa di Kecamatan Candi dengan jumlah balita total 1598 baik yang diberi ASI eksklusif maupun yang tidak diberi ASI eksklusif.

Sedangkan sampel penelitian 160 dari $10 \%$, yaitu 80 balita yang diberi ASI eksklusif dan 80 balita yang tidak diberi ASI eksklusif.

2. Observasi (pengamatan)

Observasi yaitu melakukan pengamatan secara langsung pada objek penelitian untuk melihat dari dekat kegiatan yang dilakukan.

3. Skala Perilaku Lekat

Dalam penelitian untuk mengungkap perilaku lekat bayi, maka peneliti menggunakan skala psikologi. Skala adalah suatu jenis alat pengukur dengan menggunakan sejumlah pernyataan-pernyataan tertulis yang dipakai untuk memperoleh informasi dari responden.

Dalam mengungkap perilaku lekat pda penelitian ini subyek diminta untuk menyatakan kesetujuan atau ketidaksetujuan terhadap isi pernyataan dalam empat kemungkinan jawaban: Selalu (SL), Sering (SR), KadangKadang (KD) dan Tidak Pernah (TP).

Pilihan ini telah disediakan peneliti pada setiap item-item pertanyaan atau pernyataan dan masing-masing pilihan mempunyai nilai tertentu yang telah ditetapkan oleh peneliti. Adapun untuk penskorannya, untuk pernyataan favouriabel jawaban diskor sebagai berikut:

a. Jawaban Selalu (SL) skornya 4

b. Jawaban Sering (SR) skornya 3

c. Jawaban Kadang-Kadang (KD) skornya 2

d. Jawaban Tidak Pernah (TP) skornya 1

Sedangkan untuk pernyataan Unfavouriabel jawaban diskor sebagai berikut:

a. Jawaban Tidak Pernah (TP) skornya 4 
b. Jawaban Kadang-Kadang (KD) skornya 3

c. Jawaban Sering (SR) skornya 2

d. Jawaban Selalu (SL) skornya 1

\section{Analisis Data dan Pembahasan}

Deskripsi data merupakan penjabaran dari data yang diteliti. Untuk mengetahui deskripsi perbedaan perilaku lekat bayi pada orang tua antara yang diberi ASI Eksklusif dengan yang tidak diberi ASI Eksklusif. Peneliti mengklasifikasikan dalam dua kategori yaitu tinggi dan rendah. Untuk menentukan tinggi rendahnya kecenderungan favourabilitas subyek terhadap skala perilaku lekat bayi pada orang tua antara yang diberi ASI Eksklusif, dengan yang tidak diberi ASI Eksklusif, digunakan Skor - T (Azwar, 1988:123).

Skor $\mathrm{T}=50+10\left[\frac{X-\bar{X}}{S}\right]$

Keterangan:

$\mathrm{X}=$ Skor responden yang diperoleh dari skor totalnya pada sikap

$\overline{\mathrm{X}}=$ Mean Skor kelompok

$\mathrm{S}=$ Deviasi standar kelompok

Interpretasi dilakukan dengan perhitungan bahwa $\mathrm{T}>50$ dikatakan bahwa subyek memiliki kecenderungan tinggi terhadap skala perilaku lekat bayi pada orang tua. Sebaliknya jika $\mathrm{T}<50$ subyek memiliki kecenderungan rendah terhadap skala perilaku lekat bayi pada orang tua.

Dari deskripsi data tersebut dapat diketahui bahwa kecenderungan bahwa bayi yang diberi ASI Eksklusif memiliki perilaku lekat pada orang tua yang lebih tinggi dengan Skor $68,56 \%$. Sedangkan bayi yang tidak diberi ASI Eksklusif memiliki perilaku lekat pada orang tua yang lebih rendah dengan Skor 65,84\%.
Untuk mengetahui frekuensi sebaran jawaban subyek terhadap masing-masing pernyataan serta besarnya Skor T pada bayi yang diberi ASI Eksklusif dengan bayi yang tidak diberi ASI Eksklusif dapat dilihat pada lampiran $\mathrm{C}$.

\section{Analisis Data}

Sebagai dasar pengujian hipotesis, peneliti menggunakan Uji t atau t- test. Berdasarkan tabel group statistik maka diketahui bahwa perilaku lekat bayi pada orang tua yang diberi ASI Eksklusif sebesar 2.8690, sedangkan yang tidak diberi ASI Ekslusif sebesar 2.2088. hal ini menunjukkan bahwa bayi yang diberi ASI Ekslusif memiliki perilaku lekat lebih tinggi pada orang tua tua dibanding bayi yang tidak diberi ASI Eksklusif.

Dari tabel tersebut di atas diketahui bahwa nilai probabilitas < dari 0,05 yaitu 0,000 maka pengujian ini dikatakan sangat signifikan, hal ini menunjukkan adanya perilaku lekat bayi pada orang tua antara yang diberi ASI Eksklusif dengan yang tidak diberi ASI Eksklusif.

Diketahui pula karena nilai $\mathrm{t}$ sebesar 13,832 berarti terdapat perbedaan yang sangat besar antara perilaku lekat bayi pada orang tua antara yang diberi ASI Ekslusif dengan yang tidak diberi ASI Eksklusif.

Hipotesis yang diajukan sebelumnya adalah:

"Terdapat perbedaan perilaku lekat bayi pada orang tua antara yang diberi ASI Eksklusif dengan yang tidak diberi ASI Eksklusif'.

Terdapat dua cara yang digunakan sebagai dasar pengambilan keputusan, yaitu:

1. Membandingkan $t_{\text {hitung }}$ dengan $t_{\text {tabel }}$ 
Jika $-t_{\text {hitung }}>-t_{\text {tabel }}$ atau $t_{\text {hitung }}<$ $t_{\text {tabel }}$ maka hipotesis ditolak.

Jika $-\mathrm{t}_{\text {hitung }}<-\mathrm{t}_{\text {tabel }}$ atau $\mathrm{t}_{\text {hitung }}>$ $t_{\text {tabel }}$ maka hipotesis diterima.

2. Berdasarkan nilai probabilitasnya

Jika probabilitasnya $>0,05$ maka hipotesis ditolak.

Jika probabilitasnya $<0,05$ maka hipotesis diteirma.

Berdasarkan Tabel $\quad 4.4$ probabilitasnya adalah $<0,05$ yaitu 0,000 berarti hipotesis diterima, berarti terdapat perbedaan perilaku lekat bayi pada orang tua antara yang diberi ASI Eksklusif dengan yang tidak diberi ASI Eksklusif. Berdasarkan tabel ttest, $t_{\text {tabel }}$ pada taraf kepercayaan $95 \%$ maka didapatkan $t_{\text {hitung }}>t_{\text {tabel }}$ yaitu sebesar 1,645. Oleh karena $t_{\text {hitung }}>$ $t_{\text {tabel }}$ yaitu sebesar 13,832 maka hipotesis diterima. Dengan demikian berdasarkan uji tersebut di atas terdapat perbedaan perilaku lekat bayi pada orang tua antara yang diberi ASI Eksklusif dengan yang tidak diberi ASI Eksklusif. Berdasarkan tabel group statistik maka diketahui bahwa perilaku lekat bayi pada orang tua yang diberi ASI Eksklusif sebesar 2.8690, sedangkan yang tidak diberi ASI Eksklusif sebesar 2.2088. Bayi yang diberi ASI Eksklusif akan memiliki perilaku lekat pada orang tua lebih tinggi dibanding dengan bayi yang tidak diberi ASI Eksklusif. Hal ini tergambar dari Grafik 4.1.

Kemudian untuk menentukan indikator perilaku lekat bayi pada orang tua antara yang diberi ASI Eksklusif dengan yang tidak diberi ASI Eksklusif adalah dengan melihat nilai mean tertinggi dari deskripsi statistik. Diketahui mean tertinggi pada bayi yang diberi ASI Eksklusif adalah sebesar 3,8000 (butir 1) sedangkan mean tertinggi pada bayi yang tidak diberi ASI Eksklusif adalah sebesar 2,7875 (butir 15). Hal ini menunjukkan bahwa bayi yang diberi ASI Eksklusif akan memiliki perilaku lekat lebih tinggi dibanding dengan bayi yang tidak diberi ASI Eksklusif. Selengkapnya dilampiran C.

\section{Pembahasan}

Berdasarkan analisis data dari penelitian yang dilakukan, ternyata terdapat perbedaan yang signifikan antara bayi yang diberi ASI Eksklusif dengan yang tidak diberi ASI Eksklusif. Perbedaan itu adalah pada bayi yang diberi ASI Ekslusif akan memiliki perilaku lekat lebih tinggi dibanding dengan bayi yang tidak diberi ASI Eksklusif, sehingga dpaat disimpulkan bahwa hipotesis peneliti dapat diterima, yaitu:

"Terdapat perbedaan perilaku lekat bayi pada orang tua antara yang diberi ASI Eksklusif dengan yang tidak diberi ASI Eksklusif', maksudnya adalah pada bayi yang diberi ASI Eksklusif akan memiliki kelekatan pada orang tua dibanding dengan bayi yang tidak dibeir ASI Eksklusif.

Berdasarkan teori psikoanalisa Freud (dalam Santrock, 2002:197), manusia berkembang melewati beberapa fase yang dikenal dengan fase-fase psikoseksual. Salah satu fasenya adalah fase oral, pada fase ini sumber pengalaman anak dipusatkan pada pengalaman oral yang juga berfungsi sebagai sumber kenikmatan. Secara natural bayi mendapatkan kenikmatan tersebut dari ibu disaat bayi menghisap susu dari payudara atau mendapatkan stimulasi oral dari ibu. Proses ini menjadi sarana penyimpanan energi libido bayi dan ibu selanjutnya menjadi objek cinta pertama seorang bayi. Kelekatan bayi dimulai dengan kelekatan pada payudara ibu dan dilanjutkannya dengan kelekatan pada ibu. Penekanannya disini ditujukan pada 
kebutuhan dan perasaan yang difokuskan pada interaksi ibu dan anak.

Pada tahap selanjutnya yaitu tahap perkembangan psiko sosial yang dijelaskan oleh Erik Erickson sebagai fase terbentuknya kepercayaan dasar (basic trust). Ibu dalam hal ini digambarkan sebagai figur sentral yang dapat membantu bayi mencapai kepercayaan dasar tersebut. Hal tersebut dikarenakan ibu berperan sebagai sumber pemenuhan kebutuhan bayi, menjadi sumber bergantung pemenuhan kebutuhan nutrisi serta sumber kenyamanan. Pengalaman oral dianggap Erickson sebagai prototip proses memberi dan menerima (giving and taking).

Sedangkan menurut teori belajar kelekatan antara ibu dan anak dimulai saat ibu menyusui bayi sebagai proses pengurangan rasa lapar yang menjadi dorongan dasar. Susu yang diberikan ibu menjadi primary reinforcer dan ibu menjadi secondary reinforce. Kemampuan ibu untuk memenuhi kebutuhan dasar bayi menjadi dasar terbentuknya kelekatan. Teori ini juga beranggapan bahwa stimulasi yang diberikan ibu pada bayi, baik itu visual, auditori dan taktil dapat menjadi sumber pembentukan kelekatan.

Beberapa pendapat tentang timbulnya perilakuk lekat antara lain mengatakan bahwa anak merasa tertarik pada seseorang karena sifatsifat persepsualnya atau sifat-sifat yang dapat dilihat oleh anak. Bila anak seringkali melihat orang tertentu maka ia akan mengenal sifat-sifat khusus orang tertentu itu. Bila orang tersebut ada di dekat anak maka anak akan merasa aman. Bila ada orang asing datang, anak akan bersikap negatif terhadap orang asing tersebut. Di sini timbulnya kelekatan melalui proses belajar orang-orang tertentu. Begitu juga dengan pola perilaku lekatnya, pda bayi yang diberi ASI Eksklusif akan mempunyai pola kelekatan Scurily attached infants yaitu bayi yang merasa tetap aman.

Sedangkan pada bayi yang tidak diberi ASI Eksklusif akan mempunyai dampak pada problem kelekatan yang dialami yaitu berpotensi mengalami masalah intelektual, emosional, moral dan sosial di kemudian hari dan menunjukkan pola kelekatan Insecureavoident infants, yaitu bayi-bayi merasa tidak aman dan ingin menghindar.

Diketahui nilai probabilitas < dari 0,05 yaitu 0,000 maka pengujian ini dikatakan sangat signifikan, berarti terjadi perilaku lekat bayi pada orang tua antara yang diberi ASI Eksklusif. Selanjutnya karena nilai $t$ sebesar 13,832 berarti terdapat perbedaan yang sangat besar antara perilaku lekat bayi pada orang tua antara yang diberi ASI Eksklusif dengan yang tidak diberi ASI Eksklusif.

Nilai mean tertinggi pada bayi yang diberi ASI Eksklusif adalah sebesar 3,8000 (butir 1) sedangkan mean tertinggi pada bayi yang tidak diberi ASI Eksklusif adalah sebesar 2,7875 (butir 15). Hal ini berarti terjadi perbedaan perilaku lekat bayi pada orang tua antara yang diberi ASI Eksklusif dengan yang tidak diberi ASI Eksklusif. Bayi yang diberi ASI Eksklusif akan memiliki perilaku lekat pdaa orang tua yang lebih dibanding dengan bayi yang tidak diberi ASI Eksklusif.

\section{Hasil Observasi}

Pada observasi ini, peneliti mengikuti bidan pembina desa melaksanakan kegiatan Posyandu dan peneliti menyebar kuesioner kepada 
ibu balita sambil observasi balita yang datang ke posyandu. Pada dasarnya balita yang ada di posyandu sangat familier antara satu dengan yang lainnya dan hasil dari observasi peneliti adalah sebagai berikut:

A. Bayi yang diberi ASI Eksklusif
Pada anak-anak yang
diberi $\quad$ ASI Eksklusif menunjukkan perilaku lekat yang mempunyai bentuk Aproaching behavior, Efek dari perilaku ini menyebabkan anak mendekat pada ibu, hal ini membuktikan bahwa seorang anak mempunyai kecenderungan untuk selalu dekat dengan orang lain terutama ibu dan bentuk Signaling Behavior, adapun efek dari perilaku ini adalah mendekatnya ibu pada anak, perilaku ini sebetulnya bagi anak diharapkan untuk mendapatkan dan meningkatkan kedekatan dengan ibu. Sedangkan bentuk-bentuk perilaku lekat ini dilakukan oleh anak:

1. An. G umur 28 bulan anak kedua dari dua bersaudara.

Menurut observasi peneliti ketika anak datang di posyandu dan bermain dengan temannya anak tersebut melihat ibunya terlebih dahulu, ketika ibunya mengiyakan untuk bermainmain dengan temannya dia langsung bergabung dengan teman-temannya dan sekalikali melihat ibunya, tetapi ketika ibunya beranjak dari tempat duduknya anak tersebut berlari mendekat kepada ibunya.

2. An. F umur 17 bulan anak pertama

Menurut observasi peneliti, ketika anak melihat teman- temannya bermain anak tersebut melihat ibunya terlebih dahulu dan ketika melihat orang yang tidak dikenalnya dia langsung memeluk ibunya.

3. An. A umur 19 bulan anak pertama

Menurut observasi peneliti ketika anak bermain dengan temannya dia minta ijin dulu dengan ibunya, dan ketika ada orang yang tidak dikenalnya dia melihat ibunya dan tersenyum.

4. An. D umur 21 bulan anak pertama

Ketika anak melihat temannya bermain dengan mobil-mobilan, anak tersebut minta diantar untuk bermain bersama, tidak lama kemudian anak tersebut berebut mainan sambil menoleh kearah ibunya seakan mengerti apa yang telah dikatakan oleh ibunya, lalu mainan tersebut diberikan kepada temannya dan ibu langsung memeluk anaknya.

B. Bayi yang tidak diberi ASI Eksklusif

Pada bayi yang tidak diberi ASI Eksklusif akan berpelukan sebaliknya yaitu tidak sesuai dengan bentuk-bentuk perilaku lekat tetapi menunjukkan pola kelekatan Insecure-avoident infants.

Menurut Mary Ainsworth (dalam Crain, 2007:73), bahwa bayi yang menunjukkan pola kelekatan Insecure-avoident infants adalah : bayi-bayi yang terlihat cukup independen selama menjalani situasi asing. Segera 
setelah memasuki ruangan bermain, mereka langsung memeriksa mainan yang ada di dalamnya. Meskipun mengeksplorasi seperti itu, mereka ternyata tidak menggunakan ibunya sebagai basis aman, dalam arti memeriksa kehadirannya dari waktu ke waktu. Mereka cukup mengabaikan kehadiran ibunya.

Ketika ibunya meninggalkannya di ruangan itu, mereka tidak menjadi marah, dan tidak mencari kedekatan padanya ketika ibunya kembali. Jika ibunya ingin menggendongnya, mereka berusaha menghindar, membalikkan badan atau memalingkan wajah mereka. Karena bayi-bayi ini menunjukkan independensi seperti itu dalam situasi asing, mereka berhasil mengesankan banyak orang sebagai anak yang sangat sehat, tetapi menurut Ainsworth mereka itu sebenarnya menderita kesulitan emosional dalam derajat tertentu.

Hasil observasi peneliti adalah sebagai berikut:

1. An. $\mathrm{P}$ umur 10 bulan anak pertama

Menurut observasi peneliti ketika anak tersebut selesai ditimbang, dia mau digendong oleh siapa saja, anak tersebut diam dan tidak menangis.

2. An. M umur 35 bulan anak kedua

Ketika melihat temannya bermain, dia langsung bermain dengan temantemannya dan merebut mainan temannya, ketika ibu menegurnya dia tidak menghiraukan ibunya sama sekali.

3. An. R umur 30 bulan anak pertama

Ketika datang ke posyandu anak tersebut langsung minta ditimbang dan bermain-main dengan temannya, ketika diajak ibunya pulang dia tidak menghiraukannya malah asik dengan mainannya.

4. An. K umur 28 tahun

Ketika di Posyandu anak tersebut langsung bermaintemannya, ketika diajak ibunya pulang dia tidak mau, kemudian ibunya menitipkan anaknya tersebut kepada tetangganya karena anak tersebut mau diajak oleh siapa saja.

\section{Simpulan}

Berdasarkan analisis data diketahui probabilitasnya adalah < 0,05 yaitu 0,000 berarti hipotesa diterima berarti terdapat perbedaan perilaku lekat bayi pada orang tua antara yang diberi ASI Eksklusif dengan yang tidak diberi ASI Eksklusif. Berdasarkan tabel t-test, $\mathrm{t}_{\text {tabel }}$ pada taraf kepercayaan $95 \%$ maka didapatkan nilai $t_{\text {tabel }}$ sebesar 1,960. Oleh karena $t_{\text {hitung }}>t_{\text {tabel }}$ yaitu sebesar 13,832 maka hipotesa diterima. Dengan demikian berdasarkan uji tersebut di atas terdapat perbedaan perilaku lekat bayi pada orang tua antara yang diberi ASI Eksklusif dengan yang tidak diberi ASI Eksklusif.

Dari penelitian ini dapat diketahui nilai t sebesar 13,832 berarti terdapat perbedaan yang sangat besar antara perilaku lekat bayi pada orang tua antara yang diberi ASI Eksklusif 
dengan yang tidak diberi ASI Eksklusif. Nilai mean tertinggi pada bayi yang diberi ASI Eksklusif adalah sebesar 3,8000 (butir 1) sedangkan mean tertinggi pada bayi yang tidak diberi ASI Eksklusif adalah sebesar 2,7875 (butir 15).

Hal ini berarti terjadi perbedaan perilaku lekat bayi pada orang tua antara yang diberi ASI Eksklusif dengan yang tidak diberi ASI Eksklusif. Bayi yang diberi ASI Eksklusif akan memiliki perilaku lekat lebih tinggi pada orang tua dibanding dengan bayi yang tidak diberi ASI Eksklusif.

Menurut kenyataan yang ada, perbedaan perilaku lekat bayi yang diberi ASI eksklusif adalah menunjukkan pola kelekatan scurily attached infants, yaitu bayi-bayi yang merasa tetap aman. Sedangkan bayi yang tidak diberi ASI eksklusif menunjukkan pola kelekatan insecureavoident infants, yaitu bayi-bayi merasa tidak aman dan ingin menghindar.

Setelah menganalisis hasil penelitian ini maka penulis mencoba untuk memberikan sumbangan pemikiran sebagai berikut:

a. Bagi Orang Tua

Orang tua hendaknya memiliki pengetahuan dan pemahaman bahwa perilaku lekat bayi dengan orang tua memiliki keuntungan bagi orang tua terlebih bagi bayi. Keuntungan itu berupa berkembangnya ikatan emosional atau kelekatan secara timbal balik antara bayi dengan ibu.

Begitu juga, ASI memiliki keunggulan dan manfaat yang tidak tergantikan oleh susu buatan. Keunggulan dan manfaat menyusui dapat dilihat dari beberapa aspek yaitu: aspek gizi, aspek imonologi, aspek psikologi, aspek kecerdasan, neorologis, ekonomis dan aspek penundaan kehamilan.

Sedangkan cara membuang kelekatan yang baik dengan anak terdapat beberapa cara yaitu:

1. Siapkan mental untuk menjadi orang tua

2. Ciptakan komunikasi yang hangat sejak dini

3. Upayakan program menyusui

4. Tangapilah tangisan bayi atau anak secara positif

5. Upayakan kebersamaan dalam keuarga inti

b. Bagi Masyarakat

Masyarakat hendaknya memberikan ASI Eksklusif dan meneruskan menyusui sampai bayi berusia dua tahun, karena ASI murah, efisien dan dapat diberikan kapan saja, yaitu ketika anak menangis ibu langsung bisa memberikan ASI nya dan tidak harus membuatkan susu terlebih dahulu.

c. Bagi Pendidikan

Penelitian ini merupakan salah satu penelitian yang mengkaji tentang perilaku lekat bayi pada orang tua antara yang diberi ASI Eksklusif dengan yang tidak diberi ASI Eksklusif. Dalam pelaksanaan penelitian ternyata masih sangat minim literatur yang mengulas secara detail perilaku lekat bayi pada orang tua.

Berangkat dari kondisi ini diharapkan Universitas lebih banyak menyediakan literatur tentang teori perilaku lekat, sekaligus untuk bahan penelitian lanjutan.

d. Bagi Tenaga Kesehatan

Tenaga kesehatan hendaknya mensosialisasikan tentang cara 
memberikan ASI yang baik dan manfaat pemberian ASI Eksklusif kepada masyarakat, sehingga masyarakat mengetahui dan mengerti tentang pentingnya pemberian ASI Eksklusif dan menyusui bayinya sampai umur 2 tahun.

\section{Daftar Pustaka}

Ancok, (1989). Teknik Penyusunan Skala Pengukur. Yogyakarta: Pusat Penelitian

Kependudukan Universitas Gadjah Mada.

Ariani, Dr, (2009). ASI dan Tumbuh Kembang Anak (on line) http://parentingislami.wordpres $\underline{\text { s.com (diakses tanggal } 26 \mathrm{Mei}}$ 2009).

Arikunto, S, (2002). Prosedur Penelitian Suatu Pendekatan Praktek, Edisi Revisi. Jakarta PT. Rineka Cipta

Arifin, S, MHD, (2004). Pemberian ASI Eksklusif dan Faktorfaktor yang Mempengaruhinya, www.digitized by USU.co.id. (diakses 10 Oktober 2009).

Azwar, S, (2007). Reliabilitas dan Validitas. Liberty. Yogyakarta: Pustaka Pelajar.

\section{(1988). Sikap Manusia:}

Teori dan Pengukurannya. Yogyakarta: Pustaka Pelajar.

(1999). Penyusunan Skala Psikologi. Yogyakarta: Pustaka Pelajar.

Crain, William, (2007). Teori Perkembangan, Konsep dan
Aplikasi, Edisi ketiga. Yogyakarta: Pustaka Pelajar.

Ervika, E, (2000). Kualitas Kelekatan dan Kemampuan Berempati pada Anak. Skripsi. Yogyakarta: Fakultas Psikologis Universitas Gadjah Mada (on line). http://library.usu.ac.id. (diakses 16 Juli 2009).

Gunarsa, SD, (1997). Dasar dan teori Perkembangan Anak. Jakarta: PT. BPK Gunung Mulia.

Hadi, S, (2000). Statistik. Yogyakarta: Andi Offset.

Jacinta, FR, (2002). Problem Kelekatan. (on line).e.psikologi.com. (diakses 27 Juli 2009).

Monks, dkk, (2006). Psikologi Perkembangan Pengantar Dalam Berbagai Bagiannya. Yogyakarta: Gadjah Mada University Press.

Martin, L, (1997). Pemberian ASI: Menyehatkan $\mathrm{Ibu}$ http://www.sonnenvogel.com. (Diakses 2 April 2009).

Moleong, LJ, (2000). Metodologi Penelitian Kualitatif. Bandung: PT. Remaja Rosdakarya.

Riduan, (2005). Belajar Mudah Penelitian untuk GuruKaryawan dan Peneliti Pemula. Bandung: Alfabeta.

Santrock, JW, (2002). Life-Span Development. Jilid 1. Jakarta: Erlangga. 
Sekaran, (1992). Metode Penelitian Survai. Jakarta: Alfabeta

Suryabrata, S, (1992). Pengukuran dalam Psikologi Kepribadian. Jakarta: CV. Rajawali.

Sugiono, (2003). Metode Penelitian. Jakarta: Alfabeta.

Utami, R, (2000). Asi Eksklusif. Jakarta : PT. Gramedia.
Utami, R, (2001). Mengenal ASI Eksklusif. Jakarta: Trubus Agri Widya.

Utami, R, (2007). Pemberian ASI. www.kompas.co.id. (diakses 27 Juli 2009).

Utami, R, (2007). Inisiasi Menyusu Dini, Jakarta: Pustaka Bunda.

Winarsunu, T, (2006). Statistik Dalam Penelitian Psikologi dan Pendidikan. Malang. UMM Press. 